\title{
Dog Disease Expert System Using Certainty Factor Method
}

\author{
Linda Marlinda \\ STMIK Nusa Mandiri \\ Jakarta, Indonesia \\ linda.ldm@nusamandiri.ac.id \\ Wahyu Indrarti \\ Universitas Bina Sarana Informatika \\ Jakarta, Indonesia \\ Wahyu.wii@bsi.ac.id
}

\author{
Widiyawati \\ STMIK Bani Saleh \\ Bekasi, Indonesia \\ widiyawati.zul@gmail.com \\ Reni Widiastuti \\ Universitas Bina Sarana Informatika \\ Jakarta, Indonesia \\ $\underline{\text { Reni.rws@bsi.ac.id }}$
}

Submitted: Mar 27, 2020

Accepted: Apr 1, 2020

Published: Apr 2, 2020

\begin{abstract}
Many animal keepers at home who do not know the disease contained in the animal's body. Especially for dogs, the lack of information begins to provide care, hygiene, vaccinations for the health of pet dogs and sickles that will be caused by dogs to their owners. Expert systems can provide solutions to the lack of information obtained by pet dog owners, especially dogs. With this expert system, the owner can know the dog's disease and realize the right prevention in treatment. In this paper 25, physical symptoms of the disease are used and found 8 types of common dog diseases. Five options are given to answer the calculation question using each method: no, quite sure, sure enough, certain, and certainty sure. Accuracy Analysis of each method is tested by assessing the results of each analysis method based on user feedback. The results of this study are the application of an expert system that can diagnose dogs using herbal medicines from plants. The purpose of this study is to implement the certainty factor method in the diagnosis system of canine diseases that can provide space in providing value confidence in knowledge. The conclusion in this study will show some questions as indicators of the characteristics of canine disease, until the final question. The conclusion of the study using the certainty factor method will show the characteristics of the disease in dogs. By being obtained from Rabies (0.9) with easy to get angry refuse nomal food; Hepatitis $(0,9)$ with swelling of the liver occurs; Distemser $(0,8)$ with stomach part blister and festering discharge from the eye; canine parvorius $(0,8)$ with loss of appetite and poop there is blood, herpes virus $(0,8)$ with often roared and complaints, papilomatosis $(0,9)$ with Smelly dog breath, and leptospirosis $(0,7)$ with complaints, and Dirofilaria Immitis $(0,9)$ with Unstable body temperature.
\end{abstract}

Keywords-Expert System, Dog Disease, Certainty Factor (CF)

\section{INTRODUCTION}

One of the animals that are loved by the public is a dog. Dogs can also get sick, just like humans. Many dog owners or even people don't know much about a disease that can be experienced by a dog. Diseases in dogs themselves can be contagious and not contagious (Marselena, Labellapansa, \& Syukur, 2018). The risk is that there are some dangerous dog diseases if humans are affected, for example rabies. Rabies disease affecting a dog before many did not know by the owner in advance, it was due to the lack of knowledge of the dog owner about rabies, the limitations of a veterinarian or also the problem of 
limited costs (Kristyanto \& Suria, 2018). an owner can not take care of the dog properly, it will have a bad impact on the dog. It could make the dog stress, so that it can cause the dog to get sick (Kristyanto \& Suria, n.d.). Of course there are also many factors that cause a dog to be affected by a disease, for example due to weather and temperature factors that are incompatible with the species of one type of dog, or due to battery or virus infection. In handling dog disease, different ways of handling and healing the disease. For treatments such as rabies, for example, rabies injections must be performed. Similar to those about diseases in purebred dogs, which are usually the most affected by this type of skin disease, the influencing factors can be due to environmental conditions and natural habitat, therefore as a dog owner must have knowledge in caring for dogs so as not to be mistaken in treat ("The Analysis of Comparison of Expert System of Diagnosing Dog Disease by Certainty Factor Method and DempsterShafer Method," 2013).

In the care of dogs, the owner usually still uses and relies on the expertise of experts manually, due to the limitations of the owner's knowledge of diseases that exist in dogs such as skin diseases. Of course for treatment and treatment to the vet or expert requires expensive costs, even more so the existence of a limited vet (Tse, Bullard, Rusk, Douma, \& Plourde, 2019). Therefore the need to create an expert system to help diagnose diseases in dogs, so that it is easier to deal with a dog that is affected by the disease so that care and mild treatment can still be done by the owner himself (Maniaki \& Finch, 2018). an expert system is expected that the users of this expert system can find out the symptoms in dogs affected by rabies(Muttaqin, 2019).

\section{Literature REVIEW}

The system is a study of a particular domain of knowledge that approaches the ability of humans in a field of expertise. Expert System is a knowledge of human knowledge in the field of expertise which is poured in a computer system in the form of applications that can help humans to solve a problem (Marselena et al., 2018)(Septiani \& Kuryanti, 2019).

An expert system is a series built to model the capabilities of a human expert who can help solve problems. Expert systems have now been widely used in various fields of expertise including the field of medicine that can help a doctor to diagnose an illness including pet diseases, namely dogs (Hasibuan, Sunandar, Alas, \& Suginam, 2017).
Benefits provided by the Expert System, among others:(Suhery, Midyanti, \& Hidayati, 2018)

1. Able to store large amounts of data.

2. Can store data with a fairly long period of time.

3. Complete the calculation more effectively and efficiently.

4. Can elaborate on answers to all questions surrounding a particular area of expertise

5. Can present sumsi, the flow of reasoning which if necessary is used to arrive at the desired answer.

Dogs are one of the animals that can be made friends. Because these animals can be invited to play, live with humans and be invited to socialize with humans. Dogs are the most popular pets in the world. The dog is a mammal and animal wearer of all what is commonly called an omnivore animal. With their unique abilities, adorable behavior and intelligent intelligence that easily captures what has been trained, this animal can help human activities, dogs in various kinds of environments, namely police dogs that can help police to investigate the location. In the case of accidents, breeding, etc., dogs that can herd dogs herd in a large field and also dogs deliver messages or deliver goods with a single nerve that the dog has memorized the road and the destination house of the package. With all the behavior that can be done by a dog, humans can't have a dog at home not only for one dog but can exceed.(Maniaki \& Finch, 2018)

The same thing with humans and other creatures, dogs also have limited body stability if not maintained, eating is not orderly, environmental hygiene is less noticed what happens is that the dog can be exposed to an incurable disease or a disease that causes death. As for some diseases in dogs are as follows:(Kim, Choi, \& Park, 2018)

1. Canine Parvovirus (CPV), is an important disease in dogs which is usually referred to as malignant vomiting. This disease is very contagious and is the highest cause of death, especially attacking puppies aged 1-3 months.

2. Distemper, dogs are the most common viral disease in dogs and a few truly isolated dogs are not exposed or infected by this virus. This virus is composed of RNA, helical symmetry, envelopes, the virus is rather unstable and its activity can be damaged by heat, dryness, detergents, fat solvents. Clinical symptoms("Eka Setyarini," 2013)

a. Inflammation of the mucus in the broom

b. High fever and striking the respiratory tract, digestion, and nervous system

3. Rabies or mad dog is a zoonotic infectious disease that can infect humans through the bite of a dog 
that has rabies. Rabies is a very scary and very malignant disease. Rabies directly attacks the central nervous system (brain)(Kurniati, Mubarok, \& Fauziah, 2018)

4. Infectious cannie Hepatitis is a disease caused by type 1 and 2 adeno-virus viruses. Clinical symptoms; (Munirah, Suriawati, \& Teresa, 2016)

a. At first the dog's appetite dropped so it looked lethargic and feverish with temperatures above 40 degrees. for about a week, then normal body temperature and rise again. dogs in these conditions like cold places.

b. Her eyes were swollen, continued with red eye membranes, watery discharge in the eyes and nose. in this condition dogs drink water more often because they are thirsty and tend to vomit along with pain in the abdomen and when touched on the swelling in the liver

c. Dogs often cough

5. Tapeworm is a disease that attacks dogs caused by several viruses including echinococcud granulosus, dipylidium caminum, taenia taeniaformis.

Clinical Symptoms;

a. The dog looks listless

b. Decreased appetite

c. Having mild diarrhea and abdominal pain

Dog disease along with some of the causes and clinical symptoms or ways of transmission will be the basic data for the development of an expert system using certainty factors.

\section{Proposed Method}

Certainty factor (CF) is a method in the field of expert systems in part a clinical parameter value that is given for the first time by the MYCI holder to show the trustworthiness in a particular field of expertise. This method can be used in the medical field to diagnose a disease (Suhery et al., 2018)(Marlinda, Saputra, \& Indrarti, 2019)

This uncertainty can be in the form of probability which depends on the outcome of an event. Uncertain results are caused by 2 factors: the uncertain rules of an uncertain user answer to a question raised by a system. This can be very easily seen in systems for diagnosing diseases where the experts cannot define a relationship between symptoms and their causes with certainty, and patients cannot feel things with certainty, and in the end result in many possible diagnoses(Sihotang, 2014)

The CF method shows a measure of certainty about a fact or rule. $\mathrm{CF}$ is a clinical parameter value given by MYCIN to show the amount of trust. The advantage of the CF method is that it can measure something that is certain or uncertain in making decisions in an expert system of disease diagnosis [9]. The basic formula CF (Hasibuan et al., 2017):

$$
(h, e)=(h, e)-(h, e)(1)
$$

$\mathrm{CF}(\mathrm{h}, \mathrm{e}) \quad$ Certainty Factor in the hypothesis is influenced by evidence e

MB (h, e) Measure of Belief (level of confidence), is a measure of the confidence of the hypothesis $h$ influenced by evidence (symptoms) e

MD (h, e) Measure of Disbelief (level of uncertainty), is a measure of distrust of the hypothesis $h$ influenced by symptoms e.

$\mathrm{H}$ The resulting hypothesis or conclusion (between 0 and 1)

E Evidence or events or facts (symptoms)

Strengths and Weaknesses of the Certainty Factor Method.(Setyaputri, Fadlil, \& Sunardi, 2018)

a. This method is suitable for use in expert systems that contain uncertainty in the field of medicine to diagnose a disease.

b. In one process the calculation can only process 2 data only so that the accuracy of the data can be maintained.

While certainty factor method deficiencies are:

a. Uncertainty modeling using certainty factor calculation methods is usually debated.

b. For data more than 2 pieces, data processing must be done several times

\section{RESUlt AND DISCUSSION}

Types of Dog Diseases. This knowledge base can identify dog diseases that contain disease names and disease codes.

Table 1. List of Dog Diseases

\begin{tabular}{|l|l|}
\hline Disease & The symptoms \\
\hline
\end{tabular}




\begin{tabular}{|c|c|}
\hline \multirow[t]{6}{*}{ Rabies (P1) } & Hiding in a quiet place \\
\hline & running to and fro \\
\hline & easy to get angry \\
\hline & refuse nomal food \\
\hline & Salivate \\
\hline & afraid of water \\
\hline \multirow[t]{4}{*}{ Hepatitis (P2) } & swelling of the liver occurs \\
\hline & throws up \\
\hline & high dehydration occurs \\
\hline & Fever \\
\hline \multirow[t]{10}{*}{ Distemser (P3) } & throws up \\
\hline & Fever \\
\hline & Cough \\
\hline & stomach part \\
\hline & blister and festering \\
\hline & discharge from the eye \\
\hline & fluid out of the nose \\
\hline & Complaints \\
\hline & loss of appetite \\
\hline & out of breath \\
\hline \multirow{6}{*}{$\begin{array}{l}\text { canine parvorius } \\
(\mathrm{P} 4)\end{array}$} & throws up \\
\hline & high dehydration occurs \\
\hline & lethargy occurred \\
\hline & loss of appetite \\
\hline & poop there is blood \\
\hline & $\begin{array}{l}\text { excrement emits a } \\
\text { characteristic odor }\end{array}$ \\
\hline \multirow[t]{4}{*}{ Herpesvirus (P5) } & throws up \\
\hline & often roared \\
\hline & complaints \\
\hline & $\begin{array}{l}\text { the puppy does not want to } \\
\text { breastfeed }\end{array}$ \\
\hline \multirow{2}{*}{$\begin{array}{l}\text { Papilomatosis } \\
\text { (P6) }\end{array}$} & Smelly dog breath \\
\hline & shivering \\
\hline \multirow{5}{*}{$\begin{array}{l}\text { Leptospirosis } \\
\text { (P7) }\end{array}$} & throws up \\
\hline & high dehydration occurs \\
\hline & Fever \\
\hline & complaints \\
\hline & Shivering \\
\hline \multirow{2}{*}{$\begin{array}{l}\text { dirofilaria } \\
\text { immitis (P8) }\end{array}$} & Cough \\
\hline & complaints \\
\hline
\end{tabular}

\begin{tabular}{|l|l|}
\hline & out of breath \\
\cline { 2 - 2 } & loss of appetite \\
\cline { 2 - 2 } & Unstable body temperature \\
\hline
\end{tabular}

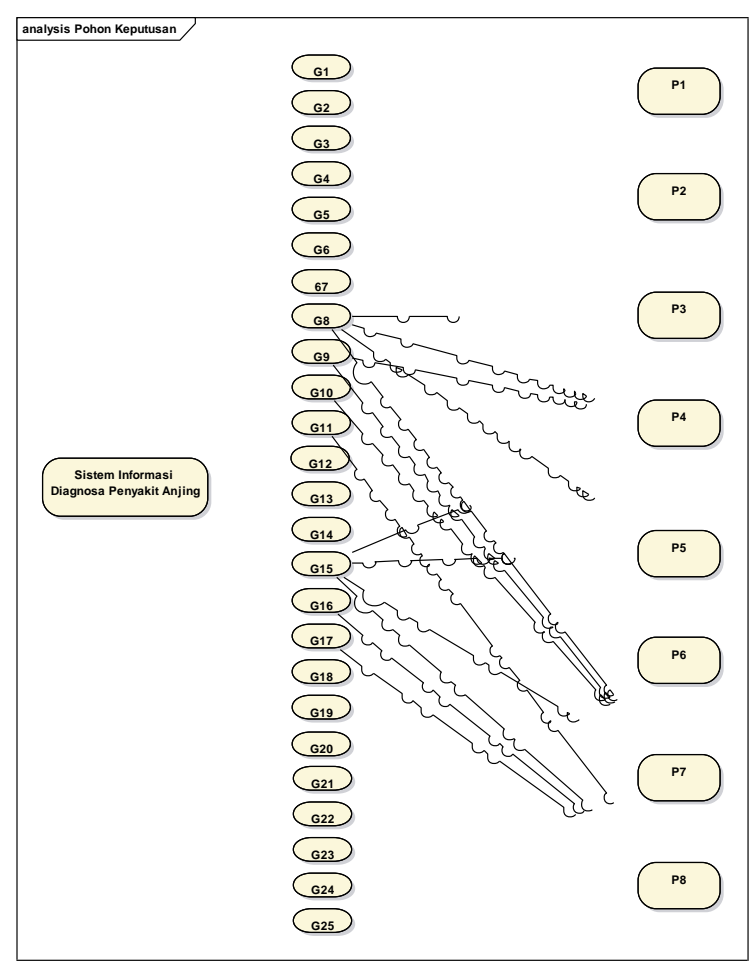

Fig. 1. Expert Tree

\section{Calculation $\mathrm{CF}$}

Patients choose the answer to symptoms like this:

1. hiding in a quiet place, with the belief "sure"

2. running to and fro, with the belief "Pretty sure"

3. quick to anger, with the belief "sure"

4. saliva, with the belief "sure"

5. refuse normal food, with the belief "Pretty Sure"

From the case examples, it shows that these symptoms are symptoms of Rabies. The patient's case above, shows that these symptoms are symptoms of Rabies

To get the level of confidence, it is calculated using the certainty factor method as follows:

1. Determine the Value of CF Users

If the value of belief has the following values 
"Sure" = 0.8

"Pretty sure" = 0.6

"Not sure" $=0.4$

"Don't know" = 0.2

Then obtained values for CF Users for each symptom are as follows

Symptoms $1=0.8$

Symptoms $2=0.6$

Symptoms $3=0.8$

Symptom $4=0.8$

Symptom $5=0.6$

2. Determine Expert Cf Value

Seen from the Expert CF Value table, for the problem in the example case above, the Expert $\mathrm{CF}$ value for each symptom is obtained

Symptoms $1=0.8$

Symptoms $2=0.8$

Symptoms $3=0.9$

Symptom $4=0.9$

Symptom $5=0.7$

3. calculate the $\mathrm{CF}$ Value rule as follows:

$\mathrm{CF}[\mathrm{H}, \mathrm{E}]=\mathrm{CF}$ (user) $* \mathrm{CF}$ (expert)

CF $1=0.8 * 0.8=0.64$

CF $2=0.6 * 0.8=0.48$

CF $3=0.8 * 0.9=0.72$

$\mathrm{CF} 4=0.8 * 0.9=0.72$

CF $5=0.6 * 0.7=0.42$

4. Finally, describe the value of $\mathrm{CF} 1$ to $\mathrm{CF} 5$

CF combine $1=\mathrm{CF} 1+\mathrm{CF} 2 *(1-\mathrm{CF} 1)$

$=0.64+0.48 *(1-0.64)$

$=0.8128$

$\mathrm{CF}$ combine $2=\mathrm{CF}$ combine $1+\mathrm{CF} 3 *(1-\mathrm{CF}$ combine 1)

$=0.8128+0.72 *(1-0.8128)$

$=0.9475$

CF combine $3=\mathrm{CF}$ combine $2+\mathrm{CF} 4 *(1-\mathrm{CF}$ combine 2)

$=0.9475+0.72 *(1-0.9475)$
$=0.9853$

$\mathrm{CF}$ combine $4=\mathrm{CF}$ combine $3+\mathrm{CF} 5 *(1-\mathrm{CF}$ combine 3)

$$
\begin{aligned}
& =0.9853+0.42 *(1-0.9853) \\
& =0.9914
\end{aligned}
$$

5. Then get a percentage of confidence in an illness

$=\mathrm{CF}$ combine $* 100 \%$

$=0.9914 * 100 \%$

$=99 \%$

Table 2 If-then table

\begin{tabular}{|l|l|l|}
\hline No & IF & Then \\
\hline 1 & $\begin{array}{l}\text { IF G1 AND G2 AND G3 } \\
\text { AND G4 AND } \\
\text { G5 AND G6 }\end{array}$ & P1 \\
\hline 2 & $\begin{array}{l}\text { IF G3 AND G5 AND G8 } \\
\text { G10 G9 AND }\end{array}$ & P2 \\
\hline 3 & $\begin{array}{l}\text { IF G3 AND G6 AND } \\
\text { G11 AND G12 }\end{array}$ & P3 \\
\hline 4 & $\begin{array}{l}\text { IF G5 AND G6 AND } \\
\text { G11 AND G12 AND G15 } \\
\text { AND G16 AND G17 }\end{array}$ & P4 \\
\hline 5 & $\begin{array}{l}\text { IF G6 AND G11 AND } \\
\text { G12 AND G16 AND G17 }\end{array}$ & P5 \\
\hline 6 & $\begin{array}{l}\text { IF G11 AND G12 AND } \\
\text { G16 AND G19 AND 20 }\end{array}$ & P6 \\
\hline 7 & $\begin{array}{l}\text { IF G21 AND G22 AND } \\
\text { G23 AND G24 }\end{array}$ & P7 \\
\hline 8 & $\begin{array}{l}\text { IF G21 AND G22 AND } \\
\text { G26 P8 }\end{array}$ \\
\hline
\end{tabular}

Table 3. Certainty Factor Value Expert

\begin{tabular}{|l|l|c|}
\hline Disease & \multicolumn{1}{|c|}{ The symptoms } & C \\
\hline Rabies (P1) & Hiding in a quiet place & 0, \\
& & 8 \\
\cline { 2 - 3 } & running to and fro & 0, \\
& & 8 \\
\cline { 2 - 3 } & easy to get angry & 0, \\
& & 9 \\
\cline { 2 - 3 } & refuse nomal food & 0, \\
& & 9 \\
\cline { 2 - 3 } & salivate & 0, \\
& & 7 \\
\hline
\end{tabular}




\begin{tabular}{|c|c|c|}
\hline & afraid of water & 0 , \\
\hline \multirow[t]{4}{*}{ Hepatitis (P2) } & $\begin{array}{l}\text { swelling of the liver } \\
\text { occurs }\end{array}$ & $\begin{array}{l}0, \\
9\end{array}$ \\
\hline & throws up & $\begin{array}{l}0, \\
3\end{array}$ \\
\hline & high dehydration occurs & $\begin{array}{l}0, \\
4\end{array}$ \\
\hline & fever & $\begin{array}{l}0, \\
4\end{array}$ \\
\hline \multirow[t]{10}{*}{ Distemser (P3) } & throws up & $\begin{array}{l}0, \\
3\end{array}$ \\
\hline & fever & $\begin{array}{l}0, \\
4\end{array}$ \\
\hline & cough & $\begin{array}{l}0, \\
6\end{array}$ \\
\hline & stomach part & $\begin{array}{l}0, \\
8\end{array}$ \\
\hline & blister and festering & $\begin{array}{l}0, \\
8\end{array}$ \\
\hline & discharge from the eye & $\begin{array}{l}0, \\
8\end{array}$ \\
\hline & fluid out of the nose & $\begin{array}{l}0, \\
2\end{array}$ \\
\hline & complaints & $\begin{array}{l}0, \\
4\end{array}$ \\
\hline & loss of appetite & $\begin{array}{l}0 \\
4\end{array}$ \\
\hline & out of breath & $\begin{array}{l}0, \\
3\end{array}$ \\
\hline \multirow[t]{6}{*}{$\begin{array}{l}\text { canine } \\
\text { parvorius }(\mathrm{P} 4)\end{array}$} & throws up & $\begin{array}{l}0, \\
4\end{array}$ \\
\hline & high dehydration occurs & $\begin{array}{l}0, \\
2\end{array}$ \\
\hline & lethargy occurred & $\begin{array}{l}0, \\
4\end{array}$ \\
\hline & loss of appetite & $\begin{array}{l}0, \\
8\end{array}$ \\
\hline & poop there is blood & $\begin{array}{l}0, \\
8\end{array}$ \\
\hline & $\begin{array}{l}\text { excrement emits a } \\
\text { characteristic odor }\end{array}$ & $\begin{array}{l}0, \\
3\end{array}$ \\
\hline $\begin{array}{l}\text { Herpesvirus } \\
\text { (P5) }\end{array}$ & throws up & $\begin{array}{l}0, \\
2\end{array}$ \\
\hline
\end{tabular}

\begin{tabular}{|c|c|c|}
\hline & often roared & 0 , \\
\hline & complaints & 0 , \\
\hline & & 8 \\
\hline & $\begin{array}{l}\text { the puppy does not want } \\
\text { to breastfeed }\end{array}$ & $\begin{array}{l}0, \\
9\end{array}$ \\
\hline Papilomatosis & Smelly dog breath & 0 , \\
\hline & shivering & 0 , \\
\hline Leptospirosis & throws up & 0 \\
\hline & & 4 \\
\hline & high dehydration occurs & 0 , \\
\hline & Fever & 0 \\
\hline & & 2 \\
\hline & complaints & 0 , \\
\hline & & 8 \\
\hline & Shivering & 0 , \\
\hline & & 0 \\
\hline $\begin{array}{l}\text { dirofilaria } \\
\text { immitis (P8) }\end{array}$ & Cough & $\begin{array}{l}0, \\
2\end{array}$ \\
\hline & complaints & 0 , \\
\hline & & 4 \\
\hline & out of breath & 0 \\
\hline & loss of appetite & 0 , \\
\hline & $\begin{array}{ll}\text { Unstable } & \text { body } \\
\text { temperature }\end{array}$ & 0 , \\
\hline
\end{tabular}

Display Interface

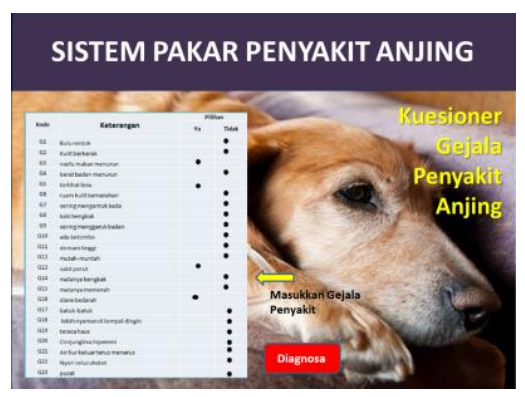

Display questionnaires for symptoms of canine disease 


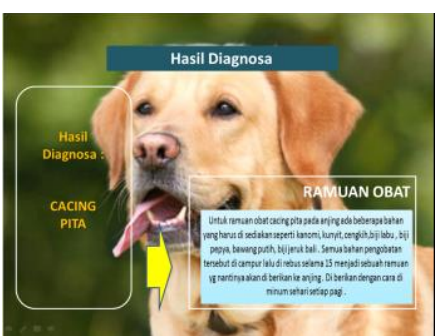

\section{Conclusion ANd Suggestion}

Disease viruses can attack all creatures created by animal gods including dogs. dogs have the right to life with proper care so they are not easily attacked by diseases. if anjig has been attacked by a disease will endanger himself and humans that are around the dog's environment. Therefore we as humans who have been given the advantage of perfect sense we should pay attention to animals including dogs.

\section{References}

Hasibuan, N. A., Sunandar, H., Alas, S., \& Suginam, S. (2017). Sistem Pakar Mendiagnosa Penyakit Kaki Gajah Menggunakan Metode Certainty Factor. Jurasik (Jurnal Riset Sistem Informasi Dan Teknik Informatika), 2(1), 29. https://doi.org/10.30645/jurasik.v2i1.16

Kim, Y. H., Choi, G. J., \& Park, C. (2018). Rate of left ventricular pressure change by Doppler echocardiography in dogs with chronic mitral valve disease at different stages of congestive heart failure. Veterinary Radiology and Ultrasound, 59(6), 758-766. https://doi.org/10.1111/vru.12664

Kristyanto, P. H., \& Suria, O. (n.d.). Sistem Pakar Diagnosa Penyakit Kulit Pada Anjing Ras Dengan Metode Teorema Bayes Expert System for Diagnosting Dog Skin Diseases Using Bayes Method, 11-20.

Kristyanto, P. H., \& Suria, O. (2018). Sistem Pakar Diagnosa Penyakit Kulit Pada Anjing Ras Dengan Metode Teorema Bayes. JMAI (Jurnal Multimedia \& Artificial Intelligence), 2(2), 1120. https://doi.org/10.26486/jmai.v2i2.77

Kurniati, N. I., Mubarok, H., \& Fauziah, D. (2018). Sistem Pakar Untuk Mendiagnosa Penyakit Hewan Peliharaan Menggunakan Metode Certainty Factor. Jurnal Teknik Informatika Dan Sistem Informasi, 4(1). https://doi.org/10.28932/jutisi.v4i1.708
Maniaki, E., \& Finch, N. (2018). Chronic kidney disease in cats and dogs: Managing proteinuria. In Practice, 40(7), 266-280. https://doi.org/10.1136/inp.k3410

Marlinda, L., Saputra, D., \& Indrarti, W. (2019). Expert System Identification Of Learning Patterns The VARK Method. SinkrOn, 3(2), 205. https://doi.org/10.33395/sinkron.v3i2.10091

Marselena, S., Labellapansa, A., \& Syukur, A. (2018). Penalaran Berbasis Aturan Untuk Diagnosa Awal Penyakit Anjing Menggunakan Teorema Bayes. Jurnal RESTI (Rekayasa Sistem Dan Teknologi Informasi), 2(2), 530 535. https://doi.org/10.29207/resti.v2i2.454

Munirah, M. Y., Suriawati, S., \& Teresa, P. P. (2016). Design and Development of Online Dog Diseases Diagnosing System. International Journal of Information and Education Technology, 6(11), 913-916. https://doi.org/10.7763/ijiet.2016.v6.816

Muttaqin, I. A. (2019). Aplikasi Diagnosa Penyakit Anjing Berbasis Web Menggunakan, 3(1), 372-379.

Septiani, M., \& Kuryanti, S. J. (2019). Sistem Pakar untuk Mendiagnosa Penyakit Saluran Pernapasan pada Anak, 2(April 2018), 23-27.

Setyaputri, K. E., Fadlil, A., \& Sunardi, S. (2018). Analisis Metode Certainty Factor pada Sistem Pakar Diagnosa Penyakit THT. Jurnal Teknik Elektro, 10(1), 30-35. https://doi.org/10.15294/jte.v10i1.14031

Sihotang, H. T. (2014). Sistem Pakar Mendiagnosa Penyakit Kolesterol Pada Remaja Dengan Metode Certainty Factor (Cf) Berbasis Web. Jurnal Mantik Penusa, 15(1), 16-23. Retrieved from http://ejurnal.pelitanusantara.ac.id/index.php/mantik/a rticle/view/161

Suhery, C., Midyanti, D. M., \& Hidayati, R. (2018). Sistem Pakar Diagnosa Penyakit Rabies Pada Anjing Menggunakan Metode Forward Chaining. Seminar Nasional Teknologi Informasi Informasi Dan Multimedia 2018, 1924.

Eka Setyarini, The Analysis of Comparison of Expert System of Diagnosing Dog Disease by Certainty Factor Method and Dempster-Shafer Method. (2013). International Journal of 
Computer Science Issues, 10(1), 576-584.

Tse, C., Bullard, J., Rusk, R., Douma, D., \& Plourde,
P. (2019). Surveillance of Echinococcus tapeworm in coyotes and domestic dogs in Winnipeg, Manitoba. Canada Communicable Disease Report, 45(7/8), 171-176. https://doi.org/10.14745/ccdr.v45i78a01 